\title{
EOQ Development Model in Optimize Raw Material Inventory
}

\author{
I Made Kartika 1,*, I Made Adi Suwandana ${ }^{2}$, I Gusti Bagus Wirya Gupta ${ }^{3}$, Putu Gede Denny Herlambang ${ }^{4}$ \\ ${ }^{1,2,3,4}$ Fakultas Ekonomi dan Bisnis Universitas Ngurah Rai, Bali, Indonesia \\ ${ }^{1}$ made.kartika@unr.ac.id *; ${ }^{2}$ adisuwandana@unr.ac.id; ${ }^{3}$ wiryagupta@gmail.com, ${ }^{4}$ denny.herlambang@unr.ac.id \\ $*$ corresponding author
}

(Received: September 1, 2021; Revised: October 25, 2021; Accepted: November 15, 2021; Available online: December 16, 2021)

\begin{abstract}
The purpose of this study was to determine the amount of safety inventory, order frequency, minimum inventory, maximum inventory limit, total Melon product inventory costs needed by PT. Rajawali Asia Bali uses the EOQ method. Data analyzed using the EOQ method shows that PT. Rajawali Asia Bali safety stock, it is very necessary to support the smooth distribution process that takes place. In accordance with the calculations with the formula, there is a safety stock that must be provided by PT. Rajawali Asia Bali is equal to 7,201 boxes. Planning for Sweet Corn products at PT. Rajawali Asia Bali using the EOQ method has 48.069 boxes.
\end{abstract}

Keywords: Raw Material Inventory, Distribution, EOQ

\section{Introduction}

Inventory is one of the most important working capital parts, because the majority of the company's business capital and MSMEs come from inventory. Trading companies often run into problems in the inventory of products to be sold, such constraints include a shortage of stock in warehouses. Controlling product distribution aims to make the desired product in accordance with the consumer's desires, the company must remain careful in determining inventory policy, because inventory requires investment costs and in this case it becomes the duty for management to determine optimal investment in inventory $[1,2]$. The inventory management is very important for the company to achieve the smooth distribution process of the product with optimal product inventory [3], it facilitates the operation of the company that must be carried out continuously because with the optimal product inventory the company can eliminate the risk of shortage of a product needed by the company and desired by the consumer [4].

Basically all companies conduct planning and control of products well with the aim of reducing the costs incurred within a certain time. In such a case the company must supply the right product so that the delivery or distribution activities of a product are not interrupted and the costs incurred in the inventory are not excessive with inventory control within a company consisting of ordering costs and storage costs. To minimize the cost of such inventory can be used "Economic Order Quantity" (EOQ) analysis. The EOQ method strives to achieve the lowest level of inventory possible, low cost and better quality. In the EOQ method in a company will be able to minimize the onion of stock so as not to interfere with the process in the company and be able to save on the cost of ordering products (ordering cost) and carrying cost incurred by the company due to the efficiency of the optimal product inventory in the company $[5,6,2]$. Product ordering costs consist of telephone fees, unloading fees and administration fees [7].

The cost of storage of the product consists of electricity costs, the cost of supervision and implementation of the warehouse, the cost of maintenance of the warehouse and the cost of insurance. One of them can also solve problems arising from the large number of stockpiles that accumulate so as to reduce the risk that can arise due to the inventory in the warehouse [8]. Distributor companies are basically parties who buy products directly from the manufacturer and sell them back to retail / retailers, and can also sell directly to the end user (end user) [9]. Another understanding 
is an organisation dependent on providing one product for use or consumption by consumers. A device of a business entity or individual responsibles for distributing or distributing trade products, be it goods or services, to retailers or end consumers. In this case, the distributor takes the finished product and is ready to be used or distributed without the need to modify it. The distributor company is the first chain after the manufacturer and distributor's company buys the product directly with a very large quantity.

Thus, the benefit of distributors from discounted purchase of products from manufacturers are the more products purchased, the bigger the discount [10]. PT. Rajawali Asia Bali is one of the companies engaged in distributors. The company has been established since 2015 located in Denpasar district. PT. Rajawali Asia Bali is one of the branches of PT. Alpen Food Industri (AFI) ice cream factory. Ice cream is a food that has long been known by the public from children to adults [11]. In hot weather ice cream can eliminate the taste of heat and thirst. One of the most popular and affordable ice cream brands is Aice brand ice cream. This Aice ice cream has a taste that is not inferior to other ice cream brands. AICE, an ice cream brand from Singapore, immediately stole the hearts of the country's ice cream lovers since its first appearance in Indonesia in 2015 [12]. AICE was the only brand from the ice cream industry to be voted the '10 most viral food of 2016 in Indonesia, winning the 'Excellent Brand Award 2017' with the highest score from the ice cream industry and AICE was also selected as the only ice cream brand of choice of Asian Games in Jakarta [13].

A wide selection of delicious and unique flavors ranging from Melon, Durian Cup, Mango Less Sugar, Pineapple, Watermelon, Green Tongue, Sesame, and others is a powerful magnet owned by AICE. With the many fans of ice cream aice this makes the company unstable to do the ordering of products on each of these variants as a result of the insanity of the amount of stock of goods in the warehouse [14]. Ordering ice cream usually takes 1 to 2 days, causing the company to be unable to meet customer demand, as well as making the company have to stop the distribution process of some of these variants and wait until the product arrives. This caused the company to suffer losses due to the absence of income. Here's a table of aice ice cream variants:

Table. 1. The Report of AICE Ice Cream Variant Product Position in 2018

\begin{tabular}{|c|c|c|c|c|c|c|c|c|c|c|c|c|c|c|}
\hline No & IENIS & JANUARI & FEBRUARI & MARET & APRIL & MEI & JUNI & IULI & AgLSTLS & SEPTEMBER & OKTOBER & NOVEMBER & DESEMBER & TOTAL FERIENIS \\
\hline 1 & MILKMELONOחم & 12,098 & 9,200 & 11,496 & 16,291 & 15,824 & 14,592 & 9,341 & 11,094 & 9,917 & 10,168 & 1,908 & 2,180 & 124,109 \\
\hline 2 & NANASח & 10,079 & 5990 & 8,096 & 8,559 & 5,002 & 8938 & 11,128 & 6,352 & 7,389 & 8,612 & 2,598 & 1,151 & 83,773 \\
\hline 3 & SQMANGKAחП & 9,379 & 7,008 & 8,931 & 10,934 & 9,400 & 8,725 & 10,640 & 5,552 & 7,655 & 8,998 & 1,652 & 2,725 & $\$ 2,121$ \\
\hline 4 & MOCHOLI & 6,313 & 7,320 & 5680 & 6,994 & 6,227 & 4,961 & 3,800 & 7,094 & 9,793 & 4,302 & 700 & 400 & 63,54 \\
\hline 5 & Bingonan & 8,186 & 8,319 & 11,637 & 12,882 & 10,795 & 12,000 & 1539 & 6,805 & 9,811 & 10,317 & 3,106 & 1,20 & 110,393 \\
\hline 6 & FUNGKYODO & 8,835 & 4,752 & 5780 & 9,999 & 8,635 & 3,960 & 7,145 & $6,6,8$ & 8,742 & 3,500 & 2,304 & 1,456 & 71,287 \\
\hline 7 & TOP COFFED O & 6,000 & 3,29 & 7,611 & 7,55 & $7,2,26$ & 11,065 & 10,085 & 3,724 & 4,190 & 5858 & 1,98 & 4,312 & 73,451 \\
\hline 8 & CONETARODO & 3,642 & 5005 & 2,553 & 2,50 & 0 & 1405 & 1,224 & 0 & $7, \infty 00$ & 6,353 & $1,6 \times 3$ & 3,781 & $§ 5,445$ \\
\hline 9 & SNE CORNDO & 5,079 & 11,98 & 6,006 & 15297 & 12,800 & 15,902 & 24,27 & 15,926 & 15,59 & 18,418 & 3,798 & 15,455 & 100,769 \\
\hline 10 & STRAWEERY CRISPYO 000 & 10,150 & 6,898 & 6,183 & 11,802 & 12,240 & 6,376 & 2,902 & 11,906 & 6,95 & 7,997 & 1,598 & 931 & 85995 \\
\hline II & COKLAT CRISPYDODOD & 11,658 & 7,351 & 11,306 & 11,011 & 9,212 & 15,113 & 10,769 & 10,50 & $8, \mathbf{n}_{1}$ & 6,754 & 1,000 & 344 & 104,239 \\
\hline 12 & MANGosuHDO & 5,345 & $2, \pi / 2$ & 4,752 & 4,790 & 3,828 & 3,520 & 3,241 & 4,693 & 4,097 & 4,145 & 400 & 399 & 41,977 \\
\hline 13 & MANGOLOWFAT D D D罗 & 11 & 0 & 0 & 0 & 0 & 0 & 39 & 184 & 0 & 0 & 0 & 0 & 罗1 \\
\hline 14 & BANANA CRISPY OODO & 0 & 0 & 0 & 0 & 0 & 0 & 0 & 0 & 0 & 0 & 0 & 0 & \\
\hline 15 & DUPAND箩口 & 0 & 0 & $\$ 94$ & 0 & 792 & 894 & 0 & 0 & 0 & 200 & 0 & 5000 & 2,980 \\
\hline 16 & SIRAMEERPY OPOOOD & 3,060 & 2,160 & 2,521 & 2,700 & 4,245 & 3,599 & 4,140 & 900 & 1,720 & 600 & 0 & 349 & 25995 \\
\hline 17 & ORLAT OPODOOD & 4,788 & 1,200 & 4,140 & 4,048 & 3,590 & 4,061 & 3,700 & 3,240 & 2,162 & 350 & 0 & $\infty 00$ & 32,479 \\
\hline 18 & FAM SIRAMRERPYO DOOD & 10 & 10 & 0 & 0 & $\infty$ & 120 & 0 & 0 & 0 & 0 & 0 & 0 & 1,020 \\
\hline 19 & FAM & 233 & 300 & 190 & 212 & 240 & 230 & 390 & 188 & 265 & 5 & 90 & 50 & 2,259 \\
\hline 20 & FAMUANULA] 000 & 30 & 10 & 30 & 0 & 0 & 0 & 0 & 0 & 0 & 0 & 0 & 0 & \\
\hline z & FAMOOKLATDODOD & 0 & 0 & 0 & 0 & 0 & 0 & 0 & 0 & 0 & 0 & 0 & 0 & \\
\hline $\mathbb{z}$ & UDAHHJAU & 0 & 8,243 & 1,472 & 0 & 3,561 & 6,292 & 0 & 0 & 0 & 0 & 0 & 0 & 19,368 \\
\hline $\mathbf{B}$ & SSAME & 0 & 0 & 0 & 0 & 0 & 0 & 1,399 & 7,726 & 4,100 & 1,008 & 200 & 1,100 & 15659 \\
\hline 24 & OTE WATLE & 0 & 0 & 0 & 0 & 0 & 0 & 1,005 & 3,794 & 900 & 4,451 & 1,100 & 1,275 & 12,546 \\
\hline $\bar{z}$ & OUE CBOR & 0 & 0 & 0 & 0 & 0 & 0 & 7,808 & 5,424 & 5,174 & 4,900 & 408 & 411 & 2,780 \\
\hline $\mathbf{2 5}$ & ODOOOOCRES & 0 & 0 & 0 & 0 & 0 & 0 & 0 & 3,202 & 1,525 & 5600 & 206 & 488 & 11,822 \\
\hline$z$ & MOOHDUPAN & 0 & 0 & 0 & 0 & 0 & 0 & 0 & 400 & 4,743 & 0 & 1,137 & 392 & 6,652 \\
\hline 28 & DUPANISIOK & 0 & 0 & 0 & 0 & 0 & 0 & 0 & 691 & 5,546 & 0 & 0 & 0 & 6,177 \\
\hline 20 & Mat-Ak & 0 & 0 & 0 & 0 & 0 & 0 & 0 & 0 & 4,000 & 7,846 & 0 & 881 & 12,677 \\
\hline 30 & MOOH OHOOLAIE & 0 & 0 & 0 & 0 & 0 & 0 & 0 & 0 & 0 & 3,305 & 0 & 300 & 3,50 \\
\hline 쿄 & & & & & & & & & & & & & & \\
\hline & & 105496 & 92,015 & 99,659 & 125,500 & 114,393 & 121,590 & 120,108 & 116,59 & 190,890 & 123,397 & 26,001 & 41,240 & \\
\hline
\end{tabular}


Table. 2. The Report of AICE Ice Cream Variant Melon Position in 2018

\begin{tabular}{|c|c|c|c|c|c|}
\hline & & \multicolumn{4}{|c|}{ PRODUK UNTUK DIJUAL } \\
\hline \multicolumn{2}{|r|}{2018} & \multirow{2}{*}{$\begin{array}{l}\text { Saldo awal } \\
\text { (Box) }\end{array}$} & \multicolumn{2}{|c|}{ MUTASI } & \multirow{2}{*}{$\begin{array}{l}\text { Saldo Akhir } \\
\text { (Box) }\end{array}$} \\
\hline No & Bulan & & Masuk & Keluar & \\
\hline 1 & Januari & 894 & 12,098 & 10,474 & 2,518 \\
\hline 2 & Februari & 2,518 & 9,260 & 8,213 & 3,565 \\
\hline 3 & Maret & 3,565 & 11,496 & 12,431 & 2,630 \\
\hline 4 & April & 2,630 & 16,291 & 14,619 & 4,302 \\
\hline 5 & Mei & 4,302 & 15,824 & 14,918 & 5,208 \\
\hline 6 & Juni & 5,208 & 14,592 & 13,830 & 5,970 \\
\hline 7 & Juli & 5,970 & 9,341 & 11,183 & 1,466 \\
\hline 8 & Agustus & 2,114 & 11,034 & 11,386 & 1,762 \\
\hline 9 & September & 1,764 & 9,917 & 11,065 & 616 \\
\hline 10 & Oktober & 616 & 10,168 & 9,998 & 10,386 \\
\hline 11 & November & 1,386 & 1,908 & 7,102 & 2,702 \\
\hline 12 & Desember & 2,702 & 2,180 & 7,222 & 341 \\
\hline & & 33,669 & 124,109 & 132,441 & 41,466 \\
\hline
\end{tabular}

From the data above can be known that PT. Rajawali Asia Bali in January the goods entered at PT Rajawali Asia Bali from the central factory is a total of 12,098 boxes and the stock comes out which is 10,474 then judging by its production there is still a stock of 2,518 of the goods entered a total of 12,098 boxes, there are excess products variant melon a total of 2,518 boxes. It also seen in the February booklan, there was a stock overspill of 3,565 boxes, in March 2,630 boxes, April was 4,302, May was 5,208,June 5,970 boxes, July 9,341 boxes, August 11,034, September 9,917 boxes, October 10,168, November 1,908 boxes and 2,180 boxes in December.

If you look at the order flow in the table above there is no regularity in the number of shipments and the final balance in the following month is also erratic and looking at the data of the last year that is January to December 2018 is caused by excess stock It requires analysis of product control so that there is no more excess products in the following Months.

\section{Research Method}

This research uses quantitative research design because in analyzing data using methods or formulas to solve a problem such as calculating the amount of product inventory at PT. Rajawali Asia Bali by using economic order quantity (EOQ) method to make product inventory optimal and launch the distribution process. Such as calculating the amount of product inventory at PT. Rajawali Asia Bali by using the Economic Order Quantity (EOQ) method to optimize product inventory and streamline the distribution process. In this study I took a research site at PT. Rajawali Asia Bali located at Jl. Cargo Permai No. 299, Ubung Kaja, Kec. North Denpasar, Denpasar City. The location is very strategic because it is easy to reach by the community.

The object in this study is controlling the supply of Aice cream oak products. Through this research the data obtained will be analyzed to find out what systems have been done and what benefits the company gets towards the implementation of optimal inventory control activities of Aice ice cream products.

\section{Result and Discussion}

The ice cream industry in Indonesia nowadays still has the opportunity to increase its growth due to the increase in per capita consumption $[15,16]$. Along with increasing public awareness of healthy food and beverages, PT. Alpen Food Industry is a company engaged in ice cream originating from Singapore and has a product named Aice. 
The company has now opened a branch in Indonesia. Aice Group is committed to producing good, healthy and affordable ice cream [17]. Aice was founded in November 2014 in Indonesia. Aice is committed to being "the most popular ice cream brand" in Southeast Asia and to deliver quality, enjoyment, freshness, happiness, innovation of ice cream products to consumers. PT. Alpen Food Industry streams Aice Ice Cream to 106 regions in Indonesia [18]. One of the subsidiaries of PT. Alpen Food Industry is PT. Rajawali Asia Bali which is selling Aice ice cream in Bali region. Bali. In running Aice ice cream industry in Bali, PT. Rajawali Asia Bali has several divisions as the spearhead of traditional market, special market, and modern market to distribute AICE products in Bali [19].

The range of Melon variant products required at PT. Rajawali Asia Bali is shipped by AICE factory in Indonesia. The next distribution of products in the warehouse will be distributed to outlets in Bali [20]. The purchase data of AICE Melon products from AICE factory can be seen in the following table:

Table. 3. Purchasing Melon's from January to December 2018 at PT Rajawali Asia Bali

\begin{tabular}{|l|l|l|}
\hline No & Bulan & Pembelian (Box) \\
\hline 1 & Januari & 12,098 \\
\hline 2 & Februari & 9,260 \\
\hline 3 & Maret & 11,496 \\
\hline 4 & April & 16,291 \\
\hline 5 & Mei & 15,824 \\
\hline 6 & Juni & 14,592 \\
\hline 7 & Juli & 9,341 \\
\hline 8 & Agustus & 11,034 \\
\hline 9 & September & 9,917 \\
\hline 10 & Oktober & 10,168 \\
\hline 11 & November & 1,908 \\
\hline 12 & Desember & 2,180 \\
\hline Jumlah & & 124,109 \\
\hline
\end{tabular}

From the data above can be tightened to know that PT. Rajawali Asia Bali makes purchases with a frequency of 12 times each year, so to calculate the average number of purchases of goods per purchase can be calculated as follows:

$$
\text { Average Purchases }=\frac{\text { Total Purchase }}{\text { Frequency }}=\frac{12,4109}{12}=10,342 \text { box }
$$

So the average number of Melon's purchased each month is 10,342 boxes. Each distribution of melon's there must be an ordering fee [21]. The cost of ordering can be interpreted as the cost incurred in connection with the attempt to obtain the product from the factory $[18,20]$. The nature of the booking fee is the higher the frequency of purchases, the greater the cost of booking. The booking fee to be borne by PT. Rajawali Asia Bali is as follows:

Table. 4. Goods Order Fee 2018

\begin{tabular}{|c|c|c|}
\hline No & Costs & Total \\
\hline 1 & Phone Charges & 14.400 .000 \\
\hline 2 & $\begin{array}{c}\text { Transportation } \\
\text { Costs }\end{array}$ & 540.000 .000 \\
\hline \multicolumn{2}{|c|}{ Total } & 554.400 .000 \\
\hline
\end{tabular}

To calculate the amount of the cost of booking one message then it can be calculated with a formula like the following.

$$
\text { Booking Fees }=\frac{\text { Total Purchase }}{\text { Frequency }}=\frac{R p .554400000}{12}=\text { Rp. } 46200000
$$

So the cost of ordering in a one-time order of melon product variant is Rp. 46.200.000.

Table. 5. Goods Order Cost 2018 


\begin{tabular}{|c|c|c|}
\hline No & Costs & Total \\
\hline 1 & Electricity Costs & 336.000 .000 \\
\hline 2 & Rental Building & 280.000 .000 \\
\hline \multicolumn{2}{|c|}{ Total } & 6.160 .000 .000 \\
\hline
\end{tabular}

To calculate the amount of storage cost per box can be calculated with the following formula.

$$
\text { Storage Costs }=\frac{\text { Storage Cost }}{\text { requirement }}=\frac{6.160 .000 .000}{124.109}=\mathrm{Rp} .4 .963,- \text { / Box }
$$

So the storage fee required by the company is $\mathrm{Rp} .4 .963$,- per box.

\section{Results Analysis}

This safety inventory is often referred to as safety stock. At PT. Rajawali Asia Bali safety stock is necessary to support the smooth production process that takes place, such as simply avoiding shortages of goods that will result in certain processes and employees not working [22]. This is very detrimental to his company. In taking into account safety supplies used statistical methods by comparing the average of goods with the actual use of goods, then searched for irregularities. The calculation of standard deviation can be seen in the following table.

Table. 6. Goods Order Cost 2018

\begin{tabular}{|c|c|r|r|r}
\hline No & Bulan & \multicolumn{1}{c|}{$\begin{array}{c}\text { Nominal } \\
\text { (Box) }\end{array}$} & \multicolumn{1}{c|}{$X-\bar{X}$} & $(X-\bar{X})^{2}$ \\
\hline 1 & Januari & 12,098 & 1,756 & $3,082,073$ \\
\hline 2 & Februari & 9,260 & $-1,082$ & $1,171,626$ \\
\hline 3 & Maret & 11,496 & 1,154 & $1,330,755$ \\
\hline 4 & April & 16,291 & 5,949 & $35,385,644$ \\
\hline 5 & Mei & 15,824 & 5,482 & $30,047,756$ \\
\hline 6 & Juni & 14,592 & 4,250 & $18,058,959$ \\
\hline 7 & Juli & 9,341 & $-1,001$ & $1,002,835$ \\
\hline 8 & Agustus & 11,034 & 692 & 478,288 \\
\hline 9 & September & 9,917 & -425 & 180,979 \\
\hline 10 & Oktober & 10,168 & -174 & 30,421 \\
\hline 11 & November & 1,908 & $-8,434$ & $71,139,385$ \\
\hline 12 & Desember & 2,180 & $-8,162$ & $66,625,046$ \\
\hline & JUMLAH & 124,109 & & $228,533,765$ \\
\hline & RATA-RATA & 10,342 & & \\
\hline
\end{tabular}

$\mathrm{SD}=\sqrt{\frac{\sum(X-\bar{X})^{2}}{N}}, \mathrm{SD}=\frac{124,129}{12}, \mathrm{SD}=4363,99$. Using the estimate or assumption that PT. Rajawali Asia Bali meets the needs of goods as much as $95 \%$ and reserve supply $5 \%$, obtaining two normal tables of 1.65 .

$$
S S=Z \times S D=1,65 \times 4346,99=7,201
$$

So, the security supply that must be provided by PT. Rajawali Asia Bali is 7,201 boxes Re Order Point is viewed with an average number of employees working for 300 days of the year. Before calculating ROP, first look for the level of use of goods per day in the following ways.

$$
d=\frac{D}{t}=\frac{124,109}{300}=414 \text { box }
$$

So the rebooking point (ROP) is as follows

$$
R O P=(d \times L)+S S=(414 \times 3)+7,201=8,441 \text { box }
$$


So, the company must rebook the goods at a rate of 8,441 boxes. Calculation of maximum inventory according to Huang et al [16], the maximum amount of inventory that the company should have is the amount of standard order (Standard order) or EOQ coupled with the size of the safety stock or with the following formation [17].

$$
M I=E O Q+S S=48,069+7,201=55,270 \text { box }
$$

So, the maximum inventory that the company should have is 55,270 boxes. The things to take into account in using the EOQ method are as follows.

1) Total need for goods (D) $=124,109$

2) One-way booking fee (S) = Rp.46.200.000,-

3) Cost of saving per box $(\mathrm{H})=\mathrm{Rp} .4,963$,-

Once known above, the size of the product for ordering using the EOQ method is:

$$
E O Q=\sqrt{\frac{2 D S}{H}}=\sqrt{\frac{2 \times 124,109 \times 46.200 .000}{4,963}}=48,069
$$

So, the number of purchases of Melon products at PT. Rajawali Asia Bali using EOQ method has 66,237 boxes. Using the EOQ method can be calculated the number of order frequencies in a year or often called the frequency of purchases, which can be calculated as follows.

$$
F=\frac{F}{E O Q}=\frac{124,109}{48,069}=3 \text { times }
$$

So, the frequency of ordering goods according to the EOQ method is 3 times a year.

\section{Conclusion}

Based on the results of this study the authors get some summations. The conclusions that can be drawn from the above discussions include In PT. Rajawali Asia Bali safety stock is indispensable to support the smooth distribution process that is taking place. According to the calculation with the formula that there is a number of safety supplies that must be provided by PT. Rajawali Asia Bali has 7,201 boxes. Melon product order planning at PT. Rajawali Asia Bali using EOQ method has 48,069 boxes. If the price needs in the distribution process are the same every year.

The company should do the distribution in each variant using the EOQ method because by using calculation the company can save on booking costs. The Company should determine what the maximum inventory benchmark is in an effort to control the security of the stock available in the warehouse.

\section{References}

[1] V. Chaudhary, R. Kulshrestha, and S. Routroy, "State-of-the-art literature review on inventory models for perishable products,” J. Adv. Manag. Res., vol. 15, no. 3, pp. 306-346, 2018, doi: 10.1108/JAMR-09-2017-0091.

[2] H. K. Chan, W. Y. C. Wang, L. H. s. Luong, and F. T. S. Chan, "Flexibility and adaptability in supply chains: A lesson learnt from a practitioner," Supply Chain Manag. An Int. J., vol. 14, no. 6, pp. 407-410, 2009, doi: 10.1108/13598540910995165.

[3] T. Afriyanti and R. Rose, "Pengaruh Inovasi Produk, Kemasan, Dan Variasi Produk Terhadap Minat Beli Ice Cream Aice Di Kota Padang,” EcoGen, vol. 1, no. September, pp. 125-140, 2019.

[4] R. F. Sari, "Seluk- Beluk Corporate Ethics Pada PT. Alpen Food Industry," J. Penelit. Pers dan Komun. Pembang., vol. 23 , no. 2, pp. 67-78, 2019, doi: 10.46426/jp2kp.v23i2.94.

[5] X. Zhu, J. Wang, B. Liu, and X. Di, "Inventory stickiness, environmental dynamism, financial constraints and survival of new SMEs in China," J. Manuf. Technol. Manag., vol. 32, no. 2, pp. 400-422, 2021, doi: 10.1108/JMTM-11-2019-0401.

[6] X. Wang, Y. Lin, and Y. Shi, "Linking industrial agglomeration and manufacturers inventory performance: the moderating role of firm size and enterprise status in the supply chain,” J. Manuf. Technol. Manag., vol. 32, no. 2, pp. 448-484, 2021, doi: 10.1108/JMTM-11-2019-0417. 
[7] X. Wang, Y. Lin, and Y. Shi, "The moderating role of organizational environments on the relationship between inventory leanness and venture survival in Chinese manufacturing," J. Manuf. Technol. Manag., vol. 31, no. 2, pp. 413-440, 2020, doi: 10.1108/JMTM-04-2019-0129.

[8] S. H. W. Stanger, R. Wilding, N. Yates, and S. Cotton, "What drives perishable inventory management performance? Lessons learnt from the UK blood supply chain," Supply Chain Manag. An Int. J., vol. 17, no. 2, pp. 107-123, 2012, doi: $10.1108 / 13598541211212861$.

[9] M. Shamsuddoha, C. Advantage, and V. Business, "Sustaining Competitive Advantage via Business Intelligence, Knowledge Management, and System Dynamics," Emerald Emerg. Mark. Case Stud., vol. 4, no. 2, 2015, doi: 10.1108/s1069-09642015000022b005.

[10] J. B. H. Yap and X. H. Ng, "Fuzzy EOQ model using possibilistic approach,” Eletronic Libr., vol. 34, no. 1, pp. 1-5, 2018.

[11] S. A. Raza and M. N. Faisal, "Inventory models for joint pricing and greening effort decisions with discounts," J. Model. Manag., vol. 13, no. 1, pp. 2-26, 2018, doi: 10.1108/JM2-07-2016-0060.

[12] L. A. Orobia, J. Nakibuuka, J. Bananuka, and R. Akisimire, "Inventory management, managerial competence and financial performance of small businesses," J. Account. Emerg. Econ., vol. 10, no. 3, pp. 379-398, 2020, doi: 10.1108/JAEE-07-2019-0147.

[13] M. Nwogugu, "Corporate governance, strategy and corporations law: The case of Jack in the Box Inc.," Manag. Audit. J., vol. 19, no. 1, pp. 29-67, 2004, doi: 10.1108/02686900410509811.

[14] M. Moardi, M. Salehi, S. Poursasan, and H. Molavi, "Relationship between earnings management, CEO compensation, and stock return on Tehran Stock Exchange," Int. J. Organ. Theory Behav., vol. 23, no. 1, pp. 1-22, 2020, doi: 10.1108/IJOTB-12-2018-0133.

[15] W. Min and L. S. Pheng, "Re-modelling EOQ and JIT purchasing for performance enhancement in the ready mixed concrete industries of Chongqing, China and Singapore,” Int. J. Product. Perform. Manag., vol. 54, no. 4, pp. 256-277, 2005, doi: $10.1108 / 17410400510593811$.

[16] C. Huang, C. Chen, R. Li, and C. Tsai, “Applying Theory of Constraint on Huang, C., Chen, C., Li, R., \& Tsai, C. (2008). Applying Theory of Constraint on Logistic Management in Large Scale Construction Sites - A Case Study of Steel Bar in TFT-LCD Factory Build-Up. Asian Journal on Quality, 9(1),” Asian J. Qual., vol. 9, no. 1, pp. 68-93, 2008.

[17] J. Gattorna, A. Day, and J. Hargreaves, “Effective Logistics Management,” Logist. Inf. Manag., vol. 4, no. 2, pp. 2-86, 1991, doi: 10.1108/09576059110143603.

[18] M. H. Avizenna, R. A. Widyanto, D. K. Wirawan, T. A. Pratama, and A. Nabila, "Implementation of Apriori Data Mining Algorithm on Medical Device Inventory System,” J. Appl. Data Sci., vol. 2, no. 3, pp. 55-63, 2021.

[19]B. Pujiarto, M. Hanafi, A. Setyawan, A. N. Imani, and E. R. Prasetya, "A Data Mining Practical Approach to Inventory Management and Logistics Optimization,” IJIIS Int. J. Informatics Inf. Syst., vol. 4, no. 2, pp. 112-122, 2021.

[20]H. Hitoshi, "The Effectiveness of The Body of Knowledge Process in The Startup Analysis of Efficiency by Applying Startup Management Body of Knowledge (SUBOK) Guide,” Int. J. Appl. Inf. Manag., vol. 1, no. 2, pp. 28-49, 2021, doi: 10.47738/ijaim.v1i2.11.

[21] W. J. Su, "The Effects of Safety Management Systems, Attitude and Commitment on Safety Behaviors and Performance," Int. J. Appl. Inf. Manag., vol. 1, no. 4, pp. 187-199, 2021, doi: 10.47738/ijaim.v1i4.20.

[22] G. Thelen, "Leadership in a Global World Management Training Requirement Using The Example of The Asian Studies Program at University of Applied Sciences (HTWG) Konstanz,” Int. J. Appl. Inf. Manag., vol. 1, no. 3, pp. 125-135, 2021, doi: 10.47738/ijaim.v1i3.14. 